\title{
Ir ao cinema em são Paulo nos anos 20
}

Sheila Schvarzman

Unicamp

\section{RESUMO}

As críticas cinematográficas de Octávio Gabus Mendes publicadas na década de 1920 em Cinearte, revista carioca dedicada ao cinema, permitem conhecer o panorama do que era exibido em São Paulo, mas também as aspirações cinematográficas do crítico e os projetos para o cinema brasileiro. Mostram a relação entre as possibilidades de desenvolvimento do cinema brasileiro e as imagens que deveria mostrar do Brasil, e o papel central que as salas de cinema tinham na constituição da atividade cinematográfica no país. Pleiteando a constituição de salas ricas em bairros de freqüência burguesa, o cinema, nas aspirações do crítico, torna-se espaço de diferenciação social, e não de inclusão. Mostram já nos anos 20 a dicotomia entre as possibilidades de constituição do cinema popular, e as aspirações elitistas que deveriam norteá-lo tanto na constituição das imagens que deveria veicular, como na sua freqüentação e distribuição espacial na cidade.

Palavras-chave: História e cinema no Brasil; História do cinema no Brasil; Década de 1920.

\section{ABSTRACT}

In the 20's, Octavio Gabus Mendes published film critics in Cinearte, a magazine on movies. His texts present an extensive coverage of the movie scene in São Paulo, as well as of his film-making ideas and his projects for Brazilian cinema. They show the relationship between the development of the Brazilian movie industry and the images they might construct about the country, and also the central role of movie theaters in the constitution of cinematographic activity in Brazil. As they look for rich theaters in rich places, movies might represent social exclusion rather than inclusion. In this process, we can see even in the 20's a dicothomy between the constitution of cinema as a popular activity and its elitist aspirations as shown by images, spaces and frequency.

Keywords: Film and history in Brasil; Brazilian film history; 20's. 


\section{INTRODUÇÃO}

Ir ao cinema é uma prática codificada e datada. Não apenas traduz um hábito, mas revela formas de freqüentação e distinção social, fruição estética, imaginações sobre a diversão e a cultura. Sua organização, ainda que tenha por base modelos estrangeiros, toma em cada local aspectos próprios que revelam amálgamas culturais e sociais. Gostaria de observar um pouco deste processo em São Paulo, durante a década de 1920, a partir do olhar do crítico Octávio Gabus Mendes em seus escritos nas revistas da época.

Observar esse processo a partir dos olhos de um crítico nos leva a indagar sobre o estatuto dessa atividade no período, que carrega com ela suas visões sobre a própria atividade cinematográfica no país, seja no que tange à exibição de filmes estrangeiros, seu formato, a constituição das salas de cinema, mas também sobre a própria produção nacional de filmes. Revela sobretudo como, no espaço das salas de cinema, e no olhar que se lança sobre elas, se constituem diferenciações sociais e culturais. É a isso que procuramos nos dedicar neste artigo.

\section{UM CINEMA PARA O BRASIL NOS ANOS 20}

No Brasil, e mais especificamente em São Paulo, o cinema começou como um divertimento de feira, essencialmente masculino, e evoluiu para uma freqüentação proletária e popular no início dos anos 20, como em outras partes do mundo onde, com a sedimentação da linguagem cinematográfica a partir de Griffith (1915), que deu aos filmes condições de contar histórias mais longas e concatenadas narrativamente, foi possível estabilizar o negócio cinematográfico. Com isso firma-se a indústria e sua produção em série, assim como se constitui uma rede estável de salas de exibição. O caminho e o formato que essas salas vão tomar depende do espetáculo, ou seja, daquilo que mostram, mas antes de tudo, do público que se tinha por alvo atingir.

Tendo nascido essencialmente como uma curiosidade popular — ainda que desde o início tenha interessado a vários setores e tomado ramificações entre artistas plásticos, cientistas, médicos, educadores, políticos e revolucionários, como na Rússia —, com as possibilidades narrativas abertas pela linguagem cinematográfica a atividade tende a se dignificar através das novas histórias que passa a contar, atraindo o público burguês, o que demanda mudanças nas práticas de exibição. Os cinemas deixam de ser apenas grandes 
galpões que reuniam trabalhadores, e passam a ser também lugares de distinção, tomando o teatro e a ópera como seus paradigmas de luxo e organização. Nos anos 20, à idéia de divertimento se acrescenta a evasão. A isso correspondia também a mudança nos conteúdos e formas, o que levava à compreensão de que o cinema não era apenas um divertimento, mas também uma arte. Entretanto, nada disso tirou do cinema o seu caráter popular.

De uma forma ou de outra, isso também ocorreu no Brasil, e mais especificamente em São Paulo. Entretanto, se aqui o cinema (a produção e a exibição) persistiu como uma prática de grande alcance popular, como acontecia em outras partes do mundo - tendo se transformado, nos Estados Unidos, numa importantíssima atividade econômica e cultural que contribuiu para a inclusão social de pobres e imigrantes —, no Brasil esse possível amálgama não era visto com bons olhos.

Desde meados dos anos 20 jovens jornalistas cariocas como Adhemar Gonzaga na revista Paratodos e Cinearte, e Pedro Lima na revista Selecta, procuram incentivar a produção de filmes nacionais e a melhoria das salas de exibição através da "Campanha pelo Cinema Brasileiro". Em suas colunas, definem as imagens do Brasil que esses filmes deveriam veicular: modernização, urbanização, juventude e riqueza, evitando o típico, o exótico e sobretudo a pobreza e a presença de negros. As salas de cinema deveriam ser extensões desse mesmo projeto: atestariam o grau de desenvolvimento e civilidade de suas populações.

Assim, o cinema que se pregava constituir no Brasil nos anos 20 era avesso ao caráter popular, tanto nas imagens como na freqüentação, procurando incentivar os aspectos artísticos da concepção fílmica, o conforto e a opulência nas salas. Na direção inversa dos americanos que massificavam a atividade para torná-la cada vez mais rendosa e viável, os jovens de classe média que imaginavam um cinema para o Brasil pensavam-no como uma atividade artística dignificante para o país, e a sua freqüência, uma forma de diferenciação e distinção social. A produção cinematográfica brasileira padecerá dessa dicotomia ao longo de sua história — basta pensar nos embates contra a Chanchada e as aspirações desmedidas da Vera Cruz durante os anos 50.

\section{SER CRÍTICO DE CINEMA}

Octávio Gabus Mendes (1904-1954) começou no cinema em São Paulo, escrevendo sobre os filmes exibidos na cidade para a revista Paratodos em 
maio de 1925 e posteriormente na revista Cinearte, ${ }^{1}$ em 1926. Desde o princípio, mescla às observações sobre os filmes comentários sobre as salas de exibição e suas condições. Na verdade, a avaliação crítica aos filmes era, nesse momento para Cinearte, indissociável de suas condições de exibição.

Quando nos referimos à crítica e à exibição ${ }^{2}$ nos anos 20, devemos abandonar os conceitos que temos hoje sobre os temas. Tanto uma como a outra eram vistas de forma distinta, mas, sobretudo, uma englobava a outra. Ricard Koszarski, escrevendo sobre os Estados Unidos, refere-se aos críticos distinguindo-os entre os reviewers, resenhistas, que resumiam o assunto dos filmes ou o material de imprensa, e os que seriam efetivamente críticos, pessoas, à época, ligadas à literatura ou a algum ramo literário - o cinema buscava nobilitar-se como arte - que procuravam algum tipo de influência pedagógica junto à audiência e aos diretores, e que faziam de suas colunas lugar de expressão de suas idéias. Um bom exemplo local deste tipo de inserção literária na crítica de cinema seria certamente o de Guilherme de Almeida, crítico d'O Estado de S. Paulo, mas podemos pensar também no bacharel Canuto Mendes Almeida, com sua preocupação moral, ou no médico legista e escritor Afrânio Peixoto. Todos ocupados em filtrar para o grande público o conteúdo veiculado pelo cinema.

Mas, certamente, o que melhor pode definir a atividade, tal como era realizada nessa época, seria a crônica e até mesmo a crônica social, na medida em que estava em pauta não exclusivamente a apreciação estética de um determinado filme, mas o espetáculo como um todo: o filme principal, os vários números artísticos que o precediam, assim como a sala, sua 'atmosfera' e os espectadores. A sala de cinema nos anos 20 é, afinal, um lugar significativo de freqüentação social, com suas matinées e soirées com programação e público determinados. Estamos num momento em que os filmes, juntamente com esse espetáculo cinematográfico que se está estabelecendo nos anos 20, voltavam-se sobretudo para o público feminino. Daí, também, a ênfase na beleza e na segurança do ambiente bom e resguardado das salas de espera, propícias aos encontros e mexericos, aonde se vai para ver e ser visto, e onde, muitas vezes, começava o próprio espetáculo com a apresentação, por uma 'Jazz Band', do "Prólogo", número artístico que introduzia o filme principal, uma grande "ouverture", como na ópera, grande espetáculo que serviu de modelo para a estruturação das exibições cinematográficas. ${ }^{3}$ Daí a importância nesse período do "palco e tela" que compunham o evento, algo comum aos Estados Unidos e ao Brasil.

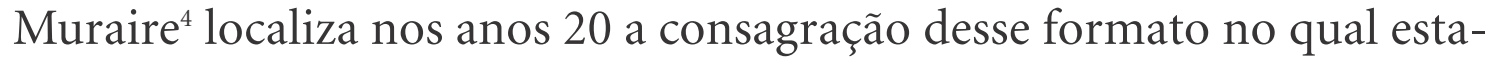


vam incluídos não apenas o cinejornal, os seriados, o filme de animação, a comédia e o filme principal, mas antes de tudo cantores, mágicos, músicos e cães amestrados. Tudo isso compunha o espetáculo, e muitas dessas programações se manterão ainda até o início do cinema falado - para a revolta de observadores como Gabus Mendes, para quem, em 1929, as apresentações artísticas amesquinhavam a exibição cinematográfica, esta sim, a principal. A avaliação de um filme não se desprendia, no cinema mudo, da observação sobre o espetáculo como um todo, nem do acompanhamento da orquestra ou do pianista.

Para os críticos do período, nos Estados Unidos, segundo Koszarski, ir ao cinema não era apenas ver um filme.

Desta forma, a crítica cinematográfica desse 'evento' continha também elementos da crônica social e da crônica literária, com suas observações sobre as pessoas e os lugares, com a atmosfera do cinema engatando no enredo do filme, nos seus astros. Nos textos dos críticos americanos do período é comum um início imaginativo, onde a fabulação começava pela descrição do público, entrava pela tela explorando o enredo e voltava-se aos atores para, por fim, enredar o público. Certamente muitos desses traços podem ser localizados à saciedade em Octávio Gabus Mendes, que costura a relação entre tela e platéia, ficção e comentário prosaico, elementos freqüentes no estilo prolixo do cronista, cujo foco de análise localiza-se antes de tudo em seu próprio olhar e gosto:

Eu estava um tanto aborrecido. Nuvens passageiras de mau humor toldavam o horizonte quase sempre límpido da minha alegria. Neste estado de ânimo é que entrei no Cine República para assistir O homem sem consciência.

A orquestra, $\mathrm{o}$ ambiente, as melindrosas e os respectivos, as pinturas exageradas, os cabelos escandalosamente curtos, saias apontando que subirão por sobre as ligas, tudo imensamente "pau". Tudo aborrecido. Enfim, lá surgem no "white board" Willard Louis, Irene Rich, John Patrick... ... Formam o enredo. Desenvolvem-no. Não chegam nem a agradar!

Como um mal [sic] final não calha no paladar dos burgueses freqüentadores de cinema aos domingos e coronel a valer, emendam um desastradíssimo final...

James Flood tem neste filme uma direção bem medíocre...

Como a freqüentação é parte da avaliação e conceituação do filme e do cinema como atividade, a localização das salas é igualmente importante, uma vez que demarca o lugar social do público. Gabus Mendes revolta-se com um 
cinema do Brás que passa ótima programação inacessível no Centro, mas lamenta que o Triângulo, o único bom cinema do centro da cidade que tem matinée, seja muito ruim: "E dizer-se que é o único cinema neste imenso São Paulo que dá matinées diárias tão necessárias para o público 'chic' que vai à cidade e que quer apreciar um filme entre a compra de uma jóia e a escolha de um vestido" (Cinearte, n.12, 19.5.1926).

Para tentar corrigir esses erros, o crítico milita pela dignificação do cinema: quer melhores salas de exibição no Centro e em bairro nobres. Em 1925, à exceção do Cine República, inaugurado em 1922, a melhor sala de São Paulo nessa época, as grandes salas estavam em bairros operários, como Brás ou Barra Funda. Nelas eram apresentados filmes de boas companhias, como a First National, fato que contraria o cronista, que achava um desperdício filmes bons serem exibidos para uma platéia, no seu entender, sem qualificações. Boas salas em bons locais garantiriam a afluência do público letrado burguês, que faria do cinema em São Paulo um espetáculo requintado e respeitado, oposto ao divertimento popular que desprezava e que, no seu entender, prejudicava a atividade.

Em 1925 e 1926 o crítico exige de Francisco Serrador ${ }^{6}$ - que se ocupava da instalação do seu quarteirão no Rio de Janeiro - que olhasse com o mesmo carinho para São Paulo, pois, com exceção do Cine República, a cidade não tinha ainda boas salas como as que se instalavam no Rio.

Mas o que estava em jogo no interesse do crítico diante da qualidade das salas e de sua freqüência? Em primeiro lugar, "o progresso de um país se mede pelo número de cinemas", como lembrava Cinearte, mas também, e sobretudo no caso de Gabus Mendes, o cinema é expressão artística elevada, própria para o consumo de elites cultas, e não apenas ou não mais divertimento popular - por isso mesmo deveria ser bem freqüentado, em locais adequados e bem situados na geografia da cidade. Como vamos notar mais detidamente a partir das observações que Gabus dedica ao tema, sua preocupação, assim como de Cinearte, era nobilitar a atividade cinematográfica — seja na realização, com os posados (filmes ficcionais), seja na exibição, através da criação de cinemas que atraíssem os "bons" freqüentadores, elevando a atividade, antes relegada às camadas populares, e sobretudo aos homens.

E a nobilitação é entendida ao pé da letra. Significava fazer da atividade de ir ao cinema um acontecimento social como o bom teatro e a ópera. Gabus Mendes em São Paulo, e Adhemar Gonzaga no Rio de Janeiro, falam das estréias bem-sucedidas lembrando a quantidade de carros de luxo que deixavam seus passageiros à porta - como acontecia no Teatro Municipal, não 
sem razão contíguo ao quarteirão que Serrador instalava no Rio de Janeiro, com as salas mais luxuosas do país até aquele momento. Octávio chega a mencionar que iria arrolar as famílias que freqüentavam as salas, mas não o faz, tratando o assunto apenas de forma genérica. Entretanto, como se pode ver em Guilherme de Almeida, n'O Estado de S. Paulo, a crítica ou crônica cinematográfica incluía também o colunismo social.

A preocupação com o enobrecimento e a ligação do cinema com a literatura como forma de "injetar respeitabilidade ao produto" mato excessivo e ornamental da escrita crítica. Imersa no parnasianismo, a linguagem de Gabus Mendes é derramada, exacerbada e subliterária, embora não se afaste dos padrões de outros como ele — não só no Brasil, mas também nos Estados Unidos, em Photoplay, ou na França, em Cinemagazine.

Entretanto, segundo Ismail Xavier, no Brasil as necessidades artísticas ligando-se ao ranço bacharelesco explicam o estilo dos nossos autores:

A colocação do cinema sob a etiqueta da arte e da indústria era conveniente aos praticantes da cultura ornamental: reverenciadores da tradição clássica, devotos do beletrismo como forma de elegância e distinção social, fascinados pelos costumes civilizados, tinham nos auspícios da arte e no modelo industrial de grande envergadura uma forma de tornar mais cultos e respeitáveis seus pronunciamentos sobre cinema. A concepção do cinema-arte, a tutela da beleza para tudo o que de nobre a noção clássica inspira num ambiente provinciano, vêm favorecer a legitimação da novidade junto aos intelectuais e burocratas. $\mathrm{O}$ interesse pelo cinema, menos nobre a princípio, pode ganhar suas compensações, desde que, no texto, o crítico dê asas ao seu progressismo ornamental e, a seu modo, reproduza o "gosto artístico" e o estilo esnobe do crítico literário. ${ }^{8}$

\section{A EXIBIÇÃo EM SÃo PaUlo}

Quantos cinemas possui esta Paulicéia querida? Creio que o número oscila entre 3 a 4 dezenas. Um cinema para cada 20 mil pessoas ...

Vão ser inaugurados novos: um todo liró, gracioso à rua Domingos de Morais, quase vis-a-vis ao Phénix; outro à Av. Tiradentes, que será fatalmente um quartel de uma nova espécie naquela via guerreira, outro ainda à Barra Funda, o Roma, nome para atrair uma multidão de patrióticos súditos de sua majestade Victor Emmanuel que moram nas vizinhanças; e o mais luxuoso e confortável, à rua São Bento. Este irá competir com o Triângulo. Ambos lutarão pela prefe- 
rência do exército de "picturers" que, após o 'footing' ... a pé ou em auto pelas ruas da cidade, dão a vida por uma fitinha.

Qual o mais simpático: o República ou o Santana? Quanto ao primeiro, dizem (os proprietários) ser o preferido da "elite" paulistana. Do segundo os proprietários dizem a mesma coisa ...

O Avenida é o mais ruidoso dos cinemas paulistanos: logo à entrada um 'jazz band' bombardeia o sistema nervoso do público. Na sala de exibição que é úmida mas bem mobiliada, acotovelam-se crianças, velhos, moços e senhores. Mas como são engraçadas as senhoras, os moços e os velhos do Avenida!

O Central é a antítese do seu colega da Av. São João. Como o Paraíso, é um cinema honesto e pacato. Freqüentam-no as meninas bem educadas dos Campos Elíseos e os velhos que sabem ser velhos.

O São Pedro, encravado na fronteira de dois bairros antagônicos - um é inimigo da gravata, outro usa sabonete Windsor — tem, por força da sua posição dois públicos. Representam-nos o 'Paschoal o bicheiro' (que resmunga contra a tirania do colarinho e a exorbitância do preço da cadeira) e a sra. Dona Maria Saudosa de Antanho, que usa "mitenes" negras e é avó de três deliciosas meninas-moças de cabelos compridos.

Outros cines existem com suas fisionomias próprias.

Cada um reflete o seu bairro, "a alma encantadora da rua" de que faz parte. Bonitos uns, feios outros, são todos, porém respeitáveis. Principalmente, os últimos, dentro dos quais o nosso povo esquece, seguindo as aventuras de um filme em séries, toda a série de desventuras que não são de celulóide. ${ }^{9}$

A crônica de Jorge Martins Rodrigues no Diário da Noite fala dos cinemas paulistanos em 1927, momento de transformação da exibição no período mudo. A escassez de boas salas de cinema que se notava em 1925 - segundo Gabus Mendes - já vinha sendo superada. Francisco Serrador já investia na cidade, e novas salas vinham sendo inauguradas no centro.

A notação do crítico é carinhosa e afetiva. Ele envereda pela crônica, e não é sem razão que faz menção a João do Rio e à sua Alma encantadora das Ruas. Rodrigues é um observador. Ele não valora, não classifica ou menospreza os diferentes bairros, cinemas ou públicos. Trata os cinemas com igual reverência: "são todos respeitáveis".

Não é esse olhar afetivo e condescendente que caracteriza a visão de Gabus Mendes sobre as salas de exibição de São Paulo. Preocupado com o progresso da exibição na cidade, com o estatuto artístico do cinema, batalha pela nobilitação do público freqüentador, pela melhoria das salas e conseqüente- 
mente dos programas apresentados. Adhemar Gonzaga fazia o mesmo no Rio de Janeiro. Como a crítica estética do filme e as condições de exibição são elementos indissociáveis, ele atua como um militante que pode e deve influenciar na atividade, e que ao fim acredita que suas intervenções foram determinantes para mudar o curso dos acontecimentos. Assim, são constantes as observações sobre as condições das salas, das orquestras e dos programas que antecediam a exibição dos filmes.

Não temos como medir a possível eficácia de sua atuação, uma vez que a condição das salas e sua melhoria não dependiam exatamente das perorações da imprensa, mas da própria evolução do negócio cinematográfico em geral. E este, nos anos 20, experimenta significativas mudanças. Francisco Serrador é quem toma a dianteira e corrige os defeitos apontados nas salas antes dirigidas por empresários italianos como Staffa e Pandolfi: desconforto, programas ruins (filmes europeus - italianos e franceses - eram vistos já como decadentes, por seu forte caráter teatral e melodramático), reprises.

Se, para a "fisionomia dos cinemas paulistanos" composta por Jorge Martins Rodrigues as salas se esparramam pelo tecido urbano sem diferenciação, para Gabus Mendes isso em si já constitui um assunto e um problema. Para ele havia uma nítida diferenciação social e cultural entre as salas e os públicos. Bons filmes não deviam ser destinados a lugares que identifica como secundários: bairros operários e de imigrantes, assim como as cidades do interior. Nesses lugares o público, segundo ele, era ignorante. Assim, indigna-se quando obras importantes são exibidas nesses locais e não no Centro, para onde convergiam a classe média e a elite. Estas ficavam privadas do bom cinema, pois era impensável transpor a Várzea do Carmo atrás de alguma fita.

IR AO CINEMA NOS ANOS 20

Como apontam Muraire e Koszarski, ${ }^{10}$ abordando os Estados Unidos, a experiência de ir ao cinema não é única nem imutável. Ao longo do tempo muda o espetáculo cinematográfico, muda o público e muda a concepção do espaço das salas. Nos anos 20 se consolida a idéia do cinema como o espetáculo da evasão popular. Grandes salas - a média é de quinhentos lugares ou mais - são construídas ou reconstruídas para criar 'atmosferas' de surpresa e emoção. Da fachada ao lobby a arquitetura da "evasão e desmesura" ${ }^{11}$ nunca identificada com um desenho contemporâneo - se encarrega de lançar o espectador para fora de seu cotidiano: o exotismo é certamente a carac- 
terística marcante. Nas salas ricamente ornadas o cinema torna-se um divertimento de massas, integrando milhões de imigrantes e uma classe média antes reticente a "freqüentar lugares com espetáculos inferiores às suas expectativas artísticas". ${ }^{12}$ A freqüência aumenta sobretudo pela afluência de crianças e adolescentes, o que explica a preocupação com a moral dos filmes. Há também uma maior feminilização do espetáculo, ou seja, tanto o filme como o espaço cinematográfico dão mais ênfase a preocupações femininas. A freqüência salta de 40 milhões, em 1922, para 65 millhões em 1928.

Certamente no Brasil, por suas condições econômicas e sociais, as coisas não se passaram de forma semelhante à observada nos Estados Unidos, embora se tenha desenvolvido a tendência a reproduzir as mudanças no que tange ao tamanho e ao estilo das salas - necessidade imposta, além do mais, pelas próprias companhias que instalaram suas filiais por aqui justamente nos anos 20, aproveitando-se do aumento do público e da freqüência aos cinemas, estimulada também pelas novas salas, o que permite, como desejavam Adhemar Gonzaga e Gabus Mendes, ampliar a freqüência das classes média e alta.

No Brasil, a exibição de filmes acompanhou, ainda que com alguma defasagem, a transformação das salas conforme se deu nos Estados Unidos. Em sua origem como divertimento popular, o cinema era exibido em cafés-concerto ou circos, como parte de espetáculos de variedades. Era, preferivelmente, um divertimento masculino. ${ }^{13}$ Mais tarde, com a crescente autonomia das exibições cinematográficas, antigos armazéns são adaptados. Trata-se de grandes salões localizados perto de regiões de concentração operária como o Brás e a Mooca, por exemplo. Com a Primeira Guerra Mundial, o advento do filme de longa metragem, a partir de Griffith, e o aburguesamento da freqüência aos cinemas, novas salas, em bairros centrais, devem surgir para abrigar esse novo público. Nos Estados Unidos isso ocorre a partir de 1915. Os cinemas deixam de ser os apenas os 'poeiras' de bairro e tornam-se 'palácios' ricamente decorados, com evocações fantasiosas de terras exóticas, com lotação em média de quinhentos espectadores e com diversos funcionários para se ocupar do novo cliente: o porteiro, o lanterninha, a moça dos doces. Nesse momento, como sinal de prestígio da sala, antecedem a exibição cinematográfica apresentações teatrais e líricas, ${ }^{14}$ resquícios da passagem das artes consagradas para a nova arte.

No Rio de Janeiro, embora já existissem, como em São Paulo, salas razoáveis no Centro, o processo de transformação e enobrecimento das salas se dá a partir de 1924, com a construção do Quarteirão Serrador. Em São Paulo esse processo se intensifica um ano mais tarde. 
Conforme podemos perceber pelas indicações de Gabus Mendes, em 1925 a exibição em São Paulo estava mudando. Havia 27 salas, ${ }^{15}$ oito delas no Centro, enquanto só no Brás havia seis, no Bom Retiro duas, na Mooca uma, no Cambuci uma e, na Vila Mariana, também uma sala. Em bairros de classe média como Paraíso, Bela Vista e Santa Cecília havia apenas uma sala. Portanto, pela localização das salas se pode perceber que o cinema era ainda em grande parte voltado aos bairros e ao público operário. "Poeiras", conforme aconteceu também nos Estados Unidos. Antigos galpões com instalações simples. No Centro, eram ainda poucas as boas salas e nem todas as companhias cinematográficas tinham sua distribuição assegurada. Algumas das salas serão reformadas, mas o número persistirá até 1927. Em 1926 surge apenas o cinema "Meia-Noite", na rua Formosa, que mesmo nos anúncios e colunas d'O Estado de S. Paulo é citado esporadicamente, sem dúvida por seu caráter exclusivamente masculino.

Diante desse quadro, o crítico paulista de Cinearte impõe-se a missão de lutar pela instalação de novas salas no Centro e tentar fazer que filmes importantes não passem apenas em cinemas de bairros operários de grande freqüentação, mas de difícil e inconveniente acesso para as classes médias, na qual ele se incluía. Era quase uma afronta que bons filmes passassem no Brás, para um público, no seu entender, desqualificado.

Não me interessa a desarmonia [entre Serrador e as companhias cinematográficas], questão monetária sem dúvida, o que sei é que para assistir um filme Serrador ou Fox era preciso aos que moravam no centro da cidade ou em bons bairros, darem uma nada confortável passeata à bond, de uns 40 minutos no máximo. É um absurdo.

... Mais uma vez, Serrador \& Cia no olho da rua, ou melhor, no Brás, de novo e mais uma vez, o público seleto precisando andar muito e arriscar os ouvidos às inconveniências para assistir filmes dos ditos Senhores. (Paratodos, n.342, 4.7.1925, p.57)

Criticado por um leitor por sua reclamação, Gabus insiste:

Quando daqui lamentei os ótimos filmes da First estarem passando lá longe no Brás, Paratodos recebeu uma carta de um cavalheiro muito interessado que dizia que o povo paulista tinha landaulet para ir ao Brás e que o público do bairro também entende o que era arte.

Será desnecessário dizer que não se discutia este ponto, é certo. Sou paulista, 
mas ainda não tenho landaulet e apesar da minha boa vontade e interesse em ver filmes, não me animava a fazer a viagem. (Paratodos, n.354, 26.9.1925, p.61)

Assim, em 1925 ainda não eram claras as mudanças em curso; não se percebia o término de uma época, com a preeminência de imigrantes italianos como Staffa ou Pandolfi, nem se esperava que o espanhol Francisco Serrador tomasse a dianteira na adequação das salas aos novos padrões mundiais desenhados a partir dos Estados Unidos.

Porém, em sentido contrário e acompanhando o sempre crescente aumento populacional dos bairros operários com a imigração ou a migração interna das fazendas para a cidade, cresciam também as salas de cinema dos bairros operários como a Mooca, o Cambuci ou a Barra Funda. Assim, em 1927 já são 35 salas, oito das quais no centro da cidade, sete no Brás, e uma em cada um destes bairros: Cambuci, Barra Funda, Liberdade, Vila Mariana e Perdizes.

A mudança e melhoria do nível das salas, que propicia a desejada nobilitação da exibição cinematográfica que vinha ocorrendo desde 1925 - lembremos o bordão de Cinearte, "o progresso de um país se mede pela quantidade de salas de cinema" - , não implicou seu abandono pelo público mais pobre, mas ao contrário o aumento do público mais abastado. Os bons cinemas para esse público se concentram no Centro ou nas franjas de bairros residenciais como Consolação, próximo da Paulista, Santa Cecília, próximo de Higienópolis e Perdizes, e até Barra Funda, como sinalizou Jorge Martins Rodrigues sobre o cine São Pedro.

Se Gonzaga e Gabus descrevem um momento da evolução das salas e do espetáculo cinematográfico de caráter mundial em que os cinemas-teatro deixavam de ser um divertimento popular híbrido dedicado a grandes platéias em bairros operários (portanto não havia ainda exibidores aqui que quisessem apostar em salas mais luxuosas como já vinha acontecendo nos Estados Unidos, e estas surgiam timidamente no Rio e em São Paulo) para tornar-se também um divertimento burguês, acrescentam a essas oscilações as preocupações locais, nas quais inserem as idéias de como deveria se desenvolver no Brasil a atividade cinematográfica - a produção e a exibição — para a qual estão certos de estar contribuindo, com seus artigos e perorações.

Nas crônicas podem ser vistos, entretanto, ecos da concepção negativa sobre o povo, característica desse momento. Por meio da Campanha pelo Cinema Brasileiro, de Cinearte, procurava-se elevar o cinema brasileiro através dos filmes de ficção evitando neles, como havia no documentário ou na 'ca- 
vação', imagens de populares, de negros, índios e paisagens naturais, imagens que distanciavam o Brasil da idéia de progresso ligada ao urbano e à modernidade. Nas salas higiênicas, concorridas, com automóveis de luxo, outras imagens e outro público criariam a imagem desejável do Brasil e da Capital Federal. Desta forma, palco e platéia estariam finalmente em consonância com a imagem branca, una, cosmopolita e sofisticada que queriam construir do país, através do cinema.

Os dois jornalistas levavam para a sala de cinema e para a imagem cinematográfica o preconceito — nada latente — forte nas duas cidades. Em São Paulo, incidindo sobre o trabalhador e o imigrante, e no Rio de Janeiro, sobre os negros.

O cronista de São Paulo aspira dar ao cinema da cidade o seu estatuto de modernidade, a sua melhor freqüentação, suas melhores orquestras. Gostaria de elevar a sua qualidade e a do seu público (deixando o que considera medíocre para as margens e as populações que entende marginais - operários, interioranos). Quer dotar o cinema brasileiro de filmes dignos desses espectadores modernos, avessos - como ele — ao dramalhão do século XIX que ainda persiste na produção de alguns imigrantes. Ao contrário dos colegas cariocas, em São Paulo ele tem de enfrentá-los, ainda que seja isso que São Paulo estivesse produzindo. Suas crônicas são a militância pela formação de um público e de salas dignas do que considera o verdadeiro cinema.

Esse tipo de raciocínio já aproxima Octávio do pensamento que Cinearte veicularia a partir de 1926: o cinema como grande arte do século XX, capaz de exprimir o índice de civilização de um povo. No entanto, percebe-se em Octávio algo mais radical: a clara separação entre um público rico e cultivado, valorizado pelo crítico, e outro popular, composto por imigrantes pouco alfabetizados e operários. A distinção entre uma platéia "seleta" e as demais.

É possível que a matriz carioca de Cinearte estipulasse distinções semelhantes, mas nos parece que Octávio operava esse tipo de discriminação de maneira mais radical do que seus colegas da metrópole, onde o hábito de ir ao cinema parece ter se sedimentado de forma mais eqüitativa e mesmo mais democrática (já no início do século Vicente de Paula Araújo dá conta da existência de uma Cinelândia no centro do Rio, onde transitavam espectadores de vários tipos, onde até mesmo a aceitação ou a rejeição ao cinema como arte era discutida de forma mais democrática).

Esse último aspecto acrescenta uma complexidade ao perfil de Gabus Mendes, na medida em que alguns de seus textos, ao menos em meados dos 
anos 20, exprimem uma maneira de fruição do cinema em São Paulo diferente daquela que se observa no Rio de Janeiro, decorrente das diferenças entre as duas cidades e da maneira como os próprios exibidores encaram o público de cinema, com os paulistas voltando-se de maneira prioritária ao público popular.

\section{O ESPETÁCULO}

Se a queixa central sobre exibição em Cinearte incidia sobre a melhoria das salas, tornando possível nobilitar o cinema a partir da freqüência de um público mais qualificado econômica, social e culturalmente, capaz de fruir devidamente a nova linguagem artística, reconhecendo portanto o estatuto que se pleiteava e reconhecia no que havia de melhor no cinema americano, a queixa subsidiária e complementar dirigia-se à forma do espetáculo cinematográfico tal como se desenvolvia naquele momento, conforme descrevemos na seção anterior. De 1925 até 1930, mesmo depois da introdução do cinema falado persistem complementos artísticos dos programas que, no entender do crítico, desvirtuam a significação e a fruição do programa principal

A reclamação se faz quanto à persistência de números musicais e artísticos. Ou seja, a exibição cinematográfica, assim como acontecia em outras partes do mundo, ainda estava ligada à antiga concepção do espetáculo popular dos teatros e feiras. Conforme Richard Koszarski, nos Estados Unidos, entre 1915 e 1928, a exibição de filmes era apenas uma parte do entretenimento, suprindo $68 \%$ do total das atrações. ${ }^{16}$

A julgar pelas constantes descrições de Gabus Mendes, os exibidores paulistas não prescindiam de apresentações do 'Jazz Band', de um cantor e de um mágico. E isso vai persistir até o início do cinema falado, apesar do anacronismo e da falta de qualidade em que ao menos Gabus nos faz acreditar por sua descrição de desusados cantores líricos, meninos talentosos, conjuntos musicais. Acredita que, mais do que servir ao cinema, atrapalham, pois desinteressariam o público.

O que mais incomoda esse crítico é o anacronismo que vê na convivência, ainda necessária para os exibidores, entre o filme e os espetáculos teatrais diversos que o antecediam. Duas formas, no seu entender, que se antagonizavam formalmente, esteticamente. Como concepção. Uma é moderna, maquínica, outras são teatrais, tradicionais, como se sobrevivessem e convivessem no palco diferentes tempos e temporalidades. O tempo do discurso teatral, 
da mimesis - e o tempo da máquina e da modernidade representada pelo cinema que reproduz o real, o seu dinamismo, o seu processo de absorção subliminar, em outra chave de percepção. Tempos distintos, sensibilidades distintas, obrigadas a conviver num mesmo espaço, onde aquele que introduz — o canto, a mágica, o jazz-band, o número teatral — apequena e desmerece o espetáculo central que é o cinema:

Agora andam anunciando uns anões. Depois virão bailarinas. Gente que devia estar fazendo companhia ao Piolin, no circo Alcebíades. E não gente para o público do Odeon que não pode achar graça nessas trupes de russos de prestação e senhoritas da Polônia que andam saracoteando horrivelmente no palco. (Cinearte, n.146, 12.12.1928)

Tenho dito que o público não aprecia mais números de palco. São viáveis em Cinemas e Arrabalde ou interior. Aonde não haja um tão elevado requinte de Cultura. Tomemos por exemplo Fu Manchu, o "maravilhoso" chinês que faz proezas no palco da sala vermelha do Odeon. Começa que ele não é chinês. Repete o programa de histórias e marrecos, caixas sem fundo, malas misteriosas. $\mathrm{O}$ público manteve-se mais frio do que Nobile após o salvamento. No Santa Helena, das Reunidas, que não querem ficar atrás do Serrador, uma companhia inteirinha de cães amestrados. Francamente em 1929, com estas coisas, me sinto amesquinhado. (Cinearte, n.170, 25.5.1929)

Reproduzindo o sistema americano que buscava rentabilizar ao máximo os filmes, permitindo que rodassem nas diversas salas de diferentes categorias (lançadores, first run, second run), a exibição de um filme depois de sua estréia não passava de no máximo dois ou três dias numa mesma sala, migrando em seguida para cinemas menos conceituados na opinião do crítico:

O Expresso Correio (The Limited Mail) ... Depois do Santa Helena, ele foi para o Triângulo e Olímpia e de lá, coitado, para Campinas, ou talvez para lugar pior, enquanto o Royal de Serrador, já exibia um filme uma semana inteira.

Mas qual, parece que eles o que querem é que a gente perca o filme no República e vá gramar um São Pedro ou um Central, onde, segundo consta, até os músicos dormem, e, se ainda tocam alguma coisa é porque o ronco é forte e o sopro produz o som. E assim estragam-se filmes em São Paulo. Tanto Ben Hur como um Big Boy Wiliams levam dois dias em cartaz e pronto! Mete-se uma pinóia no Santa Helena com equilibristas, cantores de voz rachada, etc., a 5 mil 
réis e está tudo muito bem... É tempo de São Paulo saber exibir, como se faz no Rio! (Cinearte, n.14, 2.6.1926)

O Barqueiro do Volga, filme de Cecil B. de Mille sobre a Revolução Russa, teve prólogo com coro e iluminação especial. Como foi um grande êxito de bilheteria, ficou uma semana em cartaz no República, coisa que "raramente acontece. Sob a batuta do maestro Leo Ivanow, a orquestra executou, acompanhada de um coro sofrível, a "Canção do Barqueiro do Volga”, uma das música mais lindas que conheço. Os efeitos de luz durante este trecho cantado, esteve [sic] bom" (Cinearte, n.52, 23.2.1927).

Restava ainda ao crítico se ocupar da qualidade do acompanhamento musical que naquele momento era aleatório e dependia muito da qualidade da orquestra e do cinema. Não se obedecia a partituras originais, seguindo-se apenas convenções de gênero, e por vezes nem isso. Salvo em bons cinemas que vão se implantando, sobretudo depois de 1927, a qualidade e o tamanho das orquestras vai mudando, mas a média delas segundo Gabus é muito ruim, não só por desafinarem, mas sobretudo pelo repertório inadequado. Essa característica não é apenas brasileira. Koszarsky relata comportamento semelhante nos cinemas americanos e observa que, em geral, os filmes não têm um roteiro musical ou uma partitura específica, e quando têm, esta não é executada. Os músicos e exibidores, para não pagar direitos sobre a música, preferem usar os clássicos - preferencialmente Liszt e Schubert, seja pelo acento romântico, mas sobretudo porque com eles escapavam do custo dos direitos.

Em São Paulo, o procedimento não é diferente. Gabus pegava-se muito com o Cine Triângulo, localizado no Centro, mas pela sua descrição era uma sala incômoda, com projeção ruim e orquestra pior ainda. Em A Vingança de Kremhilde, de Fritz Lang, no Triângulo, foram ouvidas:

langorosas valsas e xaroposas músicas. Isto não devem estranhar, porque lá é assim: casamento na tela, marcha fúnebre pela orquestra. Enterro na tela, marcha nupcial pela orquestra. Formidáveis! Que orquestra! Que forno! Que espelunca. (Cinearte, n.42, 14.12.1926)

E, dois anos depois, o crítico comentava:

Na sala azul do Odeon, a orquestra é boa, mas não acompanha o filme. Durante O preço da Ventura, com Billi Dove, tocaram a sinfonia d'O Guarany. E du- 
rante Frutos da época, numa cena de jazz, um trecho da Forza del Destino de Verdi! (Cinearte, n.147, 19.12.1928)

Como em 1927 ainda persistiam as apresentações artísticas antes do filme no intuito de atrair o público, Gabus chama a atenção para a nova política de distribuição da Metro através das Empresas Reunidas Metro-GoldwynMayer Ltd. Em suas salas - o Teatro Santa Helena e o Santana — se exibiriam apenas fitas. A estréia de Big Parade, prestigiado e propagandeado filme de King Vidor sobre a Primeira Guerra Mundial, marcou esse acontecimento inédito acompanhado de outros ainda mais significativos: através de discos, pelo processo Vitaphone, ${ }^{17}$ o filme realizado em 1925 seria ouvido com o seu próprio acompanhamento musical e os ruídos que a imagem demandava:

Merecem aplausos de qualquer cidadão imparcial. Quero crer que um trust nem sempre apresenta benefícios, mas o certo é, também que somente agora temos tido verdadeiros deslumbramentos cinematográficos. Filmes de raça, apresentações majestosas e em tudo, um refinado gosto artístico e uma grande vontade de agradar ... a orquestra do Santa Helena é também outra coisa que agrada muito. Além de acompanhar magnificamente o filme, está entregue à direção do tão conhecido e reputado maestro Martinez Grau que é uma competência para reger orquestras de cinema ... Por detrás do pano, ainda, um acompanhamento estupendo de tudo o que era ruído: disparos de canhões, caminhões pesadíssimos rodando, aeroplanos em vôo, metralhadores nos recordam os tenebrosos dias de julho de $1924,{ }^{18} \mathrm{e}$ assim outras coisas bem feitas. (Cinearte, n.60, 20.4.1927)

Em seu editorial, Cinearte já havia comentado essas mudanças introduzidas no Rio de Janeiro no mesmo momento. Agora se poderia assistir aos espetáculos como nos Estados Unidos, com a partitura especial, "duplo prazer, visual e auditivo".

Entretanto, pela recorrência das reclamações que persistem ainda por mais alguns anos, essa forma adequada de apresentação e acompanhamento do filme, que agradaria o público fino, na visão de Cinearte, era na verdade esporádica e só iria mudar realmente com a introdução do filme sonoro. De toda forma, os complementos artísticos de programa ainda são comentados em 1930. 


\section{“OS DEPOIS DAS ONZE"}

Como Paulo Emílio Salles Gomes ${ }^{19}$ já notou, Cinearte procurava exercer controle moral sobre a produção e a exibição de filmes. Octávio não ficava atrás de seus parceiros contra tudo aquilo que, no seu entender, escapasse às normas da boa conduta e da boa moral. Assim, critica os cinemas que se dedicam à exibição de filmes de conteúdo sexual velado sob o epíteto de Científicos ou como, diz ele, "os depois das onze", ainda que perceba que sua inclusão nos programas fosse uma estratégia de sobrevivência de certas salas, como o Triângulo e o Avenida. Pede não apenas censura, mas a intervenção da polícia e até mesmo das autoridades sanitárias para pôr fim a esse desvirtuamento do cinema:

O Avenida é o cinema "científico" das Reunidas. Quando os cofres estão pedindo reforço, zás, uma película científica. A pátria está salva.

É necessário pôr termo a essas baixezas indecentes e vergonhosas. Pretextos inconfessáveis e ignomiosos [sic] para explorar os sentimentos baixos do zé povinho ... E os que vão, pressurosos, céleres em noites assim, é simplesmente para degradar mais ainda o espírito, e mais ainda enterrar a alma no lodaçal podre da bandalheira!!! ... Eu tenho confiança que o Chefe da Polícia e o censor dêem um fim a esse gênero de espetáculo: os depois das onze. ${ }^{20}$

"A Carne de todos" (filme científico). No Avenida vaias e protesto e finalmente soldados espancando o público para manter a ordem. Vindo assim, ao encontro da minha opinião: que o público ali vai para ver espetáculo sórdido bandalho ... A higiene devia, semanalmente, fazer ali umas desinfecções salutares. ${ }^{21}$

\section{O PRECONCEITO}

Ainda que a referência às salas de exibição feita nos textos centrasse as reclamações em torno da sua localização e conforto, é claro que insistentemente Octávio Gabus Mendes está afirmando a inutilidade e a inconveniência de cinemas no Brás, Mooca e Cambuci e do público que os freqüenta, opondo a elas a prioridade de atender ao público bom, chique e seleto que, se fosse a esses cinemas, "arriscaria os ouvidos às inconveniências". ${ }^{22}$ Tais inconveniências seriam, certamente, ouvir línguas estrangeiras e tomar contato com desclassificados ou inconvenientes proletários. Gabus nesses textos não faz 
mais do que reproduzir a mentalidade dominante, que associava ao trabalhador e sobretudo ao imigrante a idéia de agitação, revolta e portanto perigo, do qual é preciso se proteger, através da segregação do trabalhador e do mundo do trabalho.

$\mathrm{Na}$ verdade, a geografia da cidade, dividia as regiões altas e salubres, onde estavam os bairros de habitação de classe alta e média, das regiões baixas, próximas da várzea dos rios, sujeitas a inundações, compostas por indústria e habitações pobres. Por si só essa diferenciação já afastava e segregava o convívio entre diferentes núcleos sociais da cidade. Entretanto, a ela se somava o fato de que estas regiões que misturavam habitações simples, cortiços e fábricas, eram também mal cuidadas, mal iluminadas, com ruas que, na sua maioria, não eram calçadas. Além disso, essas regiões concentravam operários que eram, em sua maioria, estrangeiros. Como lembra Foot Hardman, "o que a massa dos senza pátria teria como contribuição, numa pátria de bacharéis e oligarcas, a não ser sua própria presença, por si só portadora de um sentido revolucionário, e por isso mesmo, tão incômoda e arriscada aos olhos das classes dominantes e seu Estado?". ${ }^{23}$

Desta forma, as populações pobres são dispensáveis e devem ser dispensadas de entrar em cena, não apenas nos filmes brasileiros que Cinearte idealizava mas também nas salas de cinema que constituiriam o país adiantado com que os críticos sonhavam.

Eventualmente, o imigrante também podia ser estigmatizado por vender mercadorias de porta em porta ou praticar agiotagem, alusão certamente aos imigrantes judeus, que na época recebiam também o tratamento de russos. Escrevendo sobre Dança rubra, um dos inúmeros filmes americanos feitos sobre a Revolução Russa naquele período, a revista observava que:

É mais uma história da Rússia. Direção Raoul Walsh. Já não nos bastam a dúzia e meia de russos que andam diariamente pelas ruas que percorremos, apregoando mercadorias e prestações ... já não bastam a dúzia e meia de russos que são o pesadelo do dinheiro que recebemos ... E ainda por cima, semanalmente temos que aturar, no mínimo um filmezinho assim. (Cinearte, n.168, 15.5.1929)

\section{ENSAIANDO UMA CONCLUSÃO}

Ao basear a análise da exibição em São Paulo no olhar de Octávio Gabus Mendes, há certamente uma visão parcial. E ela não é apenas parcial. É também elitista, conservadora e despreza o que foge à norma, à centralidade que 
ele acredita representar. É contra a cultura popular, o cinema de bairro, a cidade distante e o interior, o estrangeiro. Entretanto, Gabus era representativo do tipo de pensamento das elites e não destoa em absoluto dos seus colegas cariocas que mantêm a revista Cinearte, eles também nutrindo o mesmo tipo de preconceitos.

Como se pôde ver pelas observações aqui arroladas, nas quais procuramos explorar prioritariamente a descrição sumária sobre a exibição em São Paulo, há em Gabus um projeto de exibição que, ao privilegiar a boa sala e a boa programação em bairros centrais, deixa claro não apenas o desinteresse, mas em certa medida a clara aversão à ligação das camadas populares com o cinema. Elas não somam, não influem, não influenciam e não entendem de cinema. A elas deve destinar-se tudo aquilo de interesse menor. Não há sequer um projeto pedagógico visando sua integração ao mercado de consumidores, embora reconheça, com contrariedade, que os pobres dispõem de cinemas e até mesmo de boa programação. Gabus e os críticos de Cinearte miram não a quantidade das salas como apregoam, mas certamente a qualidade e o elitismo de seus freqüentadores. O público popular não lhes interessa, sequer, como pagante em potencial que poderia aderir ao cinema brasileiro.O povo - e aqui é claro que parte são trabalhadores assalariados, imigrantes, estrangeiros, populações rurais e do interior, pobres e negros — pode e deve passar ao largo de produções culturais significativas. Certamente deve ficar também restrito aos seus cinemas de bairro distante.

Ao contrário dos americanos que tanto admiravam e que, sim, produziam para a massa, os ideólogos de Cinearte, entre eles Octávio Gabus Mendes, por força de sua formação cultural, por força de seu elitismo, não são capazes de formular ou mesmo perceber as possibilidades de sustentação econômica do cinema voltado para o grande público popular. Como bem observa Foot Hardman:

No Brasil, bem antes da "invasão" das ruas e jardins públicos pela classe operária, a segregação feita pela classe dominante chegava a níveis dignos da préhistória da cidadania. A questão social combinava-se com a questão nacional: o proletariado, aos olhos do discurso dominante, tornava-se ameaçador por sua dupla condição de assalariado e estrangeiro. ${ }^{24}$

Procurando indagar sobre quem são esses operários que enchem mais da metade dos cinemas da cidade no período mudo, as referências têm que ser buscadas nos livros de memória, nos jornais operários. Livros como os de Guzzo $^{25}$ e de Foot Hardman, ${ }^{26}$ dedicados à vida fora das fábricas ou à militân- 
cia operária, colocam o cinema como uma das formas de lazer dos trabalhadores, mas não incluem nenhum exemplo concreto ou significativo, ${ }^{27}$ uma vez que se dedicam a descrever práticas em tudo contrárias, em ideologia e aspirações, àquelas veiculadas pelo cinema, sobretudo o americano. Hardman lembra, no entanto, a extração imigrante e proletária de vários diretores e também de filmes realizados por estes, que documentaram movimentos ou encontros anarquistas, conforme já conhecemos pela Filmografia de Jean Claude Bernardet. ${ }^{28}$ Mas esses autores não procuraram deter-se sobre a influência, ligação ou papel que essa atividade pode ter significado para trabalhadores, nem sequer pelas vias do imaginário que os filmes certamente ajudaram a compor. É ainda um trabalho a ser feito.

O cinema que visa Octávio Gabus Mendes, seja com a exibição de filmes estrangeiros, seja com a produção de filmes nacionais, é o 'cinema de prestígio' voltado para as camadas urbanas educadas. O cinema não é negócio, embora quisessem implantar uma indústria. Cinema é uma expressão artística que afirma e expõe a diferenciação e a elevação social do país. Herdeiros da mentalidade ibérica contrária ao fazer manual, as elites econômicas letradas nas quais se inserem os membros de Cinearte desprezam o povo até mesmo como consumidor. O cinema brasileiro padecerá desse mal.

\section{NOTAS}

${ }^{1}$ A revista Cinearte surgiu em 1926, a partir do empenho de Adhemar Gonzaga. Embora a publicação seja dedicada prioritariamente ao cinema americano, Gonzaga junto com Pedro Lima escrevem sobre cinema brasileiro. Observando, incentivando e criticando a produção nacional, desenvolvem sua "Campanha pelo Cinema Brasileiro", tentando implantar uma produção estável de filmes e o respeito dos exibidores aos filmes nacionais, censurando a produção de filmes de propaganda ou reportagens sobre o país, feitas sobretudo por imigrantes que, no seu entender, veiculavam imagens negativas sobre o país. Para isso, indicavam a forma adequada de filmar o Brasil: técnica cinematográfica atualizada, padrões urbanos, modernos, extirpando da imagem notações locais, típicas, evitando a imagem de pobres e negros. Octávio Gabus Mendes é o representante paulista desse ideário exposto em sua coluna "De São Paulo".

${ }^{2}$ Utilizamos BORDAT, F. e ETCHEVERRY, M. Cent ans d'aller au cinema. Rennes: Presses Universitaires de Rennes, 1995; KOSZARSKI, R. An Evening's entertainment: the age of the silent feature picture: 1915-1928. Los Angeles: University of Califórnia Press, 1994; GONZAGA, A. Poeiras e Palácios. Rio de Janeiro: Record, 2000; Xavier, I. Sétima arte, um culto moderno. São Paulo: Perspectiva, 1978; XAVIER, I. O palco e a cena. São Paulo: Cosac \& Naify, 2003; SALIBA, M. E. F. Cinema Contra Cinema. São Paulo: Annablume, Fapesp, 2003.

${ }^{3}$ XAVIER, I. O olhar e a cena. São Paulo: Cosac \& Naify, 2003. 
${ }^{4}$ MURAIRE, A. Aller aux cinema aux annés 20. In: BORDAT, F. (Org.) Cent Ans d'aller au Cinema, Rennes: Presses Universitaire de Rennes, 1995, p.43.

${ }^{5}$ Cinearte, n.2, 10.2.1926.

${ }^{6}$ Francisco Serrador, imigrante espanhol, ex-ator, foi um importante exibidor que modificou o espetáculo cinematográfico em cidades como Rio de Janeiro e São Paulo. Ver SOUZA, J. I. de. Imagens do passado. São Paulo: Senac, 2004.

${ }^{7}$ XAVIER, I. Sétima arte, um culto moderno, op. cit., p.124.

${ }^{8}$ Ibidem.

${ }^{9}$ Cinearte, n.55, 16.11.1927. Artigo transcrito do Diário da Noite, (Rio de Janeiro), sem data.

${ }^{10}$ MURAIRE, A. Aller aux cinema aux anées 20, op. cit.; KOSZARSKI, R. An Evening's entertainment: the age of the silent feature picture: 1915-1928. Los Angeles: University of Califórnia Press, 1994.

${ }^{11}$ Termo de Lewis Munford, in: BORDAT, F., op. cit., p.39.

${ }^{12}$ BORDAT, F., op. cit., p.40.

${ }^{13}$ ASSEF, A. G. Palácios e Poeiras. Rio de Janeiro: Record, Funarte, 1996.

${ }^{14}$ SKLAR, R. Movie-Made America. s.l.: Vintage Book Edition, 1994.

${ }^{15}$ Conforme a coluna de cinemas d'O Estado de S. Paulo nesse período.

${ }^{16}$ KOSZARSKI, R. An Evening's Entertainment, op. cit., p.9.

${ }^{17}$ Processo de som sincronizado através de discos.

${ }^{18}$ Como o filme se refere à Primeira Guerra Mundial, o crítico evoca a recordação da Revolução de 1924 em São Paulo.

${ }^{19}$ GOMES, P. E. S. Humberto Mauro, Cataguases, Cinearte. São Paulo: Perspectiva, 1974.

${ }^{20}$ Correspondência, Octávio Gabus Mendes a Adhemar Gonzaga, 13.3.1929.

${ }^{21}$ Correspondência, Octávio Gabus Mendes a Adhemar Gonzaga, 20.3.1929.

${ }^{22}$ Paratodos, n.342, 4.7.1925, p.57.

${ }^{23}$ HARDMAN, F. F. Nem pátria, nem patrão. São Paulo: Ed. Unesp, 2002, p.68.

${ }^{24}$ Ibidem, p.55.

${ }^{25}$ DECCA, M. A. G. A vida fora das fábricas. São Paulo: Paz e Terra, 1987.

${ }^{26}$ HARDMAN, F. F., op. cit.

${ }^{27}$ GUZZO observa que a entrada de cinema significava 1\% do salário de um trabalhador, o que era muito caro e certamente impedia uma freqüência maior.

${ }^{28}$ HARTMANN baseia-se em informações de BERNARDET, J. C. Filmografia do Cinema Brasileiro 1900-1935. São Paulo: Secretaria da Cultura, Comissão de Cinema, 1979.

Artigo recebido em 03/2005. Aprovado em 05/2005 